\title{
Interaction between micronutrients; vitamin a, zinc and iron in the eye (biochemical and histological studies)
}

\author{
*Margeret A. Aziz, *Anhar M. Gomaa, **Laila K. Hanafy, \\ ***Fatma Abd EL - Hady Soliman . \\ *Biochemistry Department, ${ }^{* *}$ Histology Department, ***Ophthalmic \\ Genetic Department, Research Institute of Ophthalmology
}

\begin{abstract}
The association of visual impairment and poor diet has long been recognized. The retina and retinal pigment epithelium have the highest trace mineral content as compared to any body tissue. Malnutrition as a cause of blindness has been under estimated. This study aimed to investigate the relation between both deficiency as well as the excess of micronutrients (Vitamin A, zinc and iron) and the ocular eye diseases. This work was done on 48 albino rats divided into six groups. Group one fed on control basal diet, group two, three and four were fed on a diet free from vitamin A, iron, and zinc respectively. Group five was fed on a diet free from all the above micronutrients while group six was fed on a diet contain excess of all these micronutrients. At the end of the feeding period, ophthalmological and histological examinations were done to all rats. The level of vitamin A was estimated in the serum and the concentration of zinc and iron were determined in the cornea, lens and retina. Also total protein and its fractions were estimated in the lens. The result of this study showed that cortical cataract was detected in the rats fed on the diet containing deficient or excess micronutrients. The level of vitamin $A$ in serum and the concentration of iron and zinc in cornea, lens and retina revealed a significant change in different tissues studied due to different treatment especially in deficient and excess groups. Histological examination revealed photoreceptor degeneration in the retina and intact endothelial cells of the cornea. The data of this work also revealed that the level of these micronutrients in the diet affect ocular function, therefore they have to be provided in adequate amounts that satisfy the physiological requirements to avoid eye complications.
\end{abstract}

\section{INTRODUCTION}

Nutrition deficiency is regarded as one of the widespread risk factors, contributing to different eye diseases. Most nutrition specialists regarded micronutrients deficiencies as serious problem in the area. The fact that half of the world's population had to cope with deficiencies of vitamin A, zinc, and iron was widely ignored. Only relatively few researchers recognized the problems and challenged established viewpoint ${ }^{(1)}$.

Vitamin A is essential for the visual system. It is metabolized in the retina and greatly affects the structure and function of retinal pigment 
epithelial (RPE) cells. Vitamin A modulates the structure and antiangiogenic function of the RPE layer $^{(2)}$.

Zinc has long been recognized as an essential constituent of various tissues through its role in the activity of many enzymes such as superoxide dismutase and catalase. The highest concentration of zinc in the body is observed in the eye particularly pigments containing components ${ }^{(3)}$.

Strong correlations between vitamin A status and hemoglobin levels or vitamin A and zinc for treatment of different nutritional disorder have been demonstrated by kolsteren, et al. ${ }^{(4)}$ and Munoz, et al. ${ }^{(5)}$ who showed that supplementation for 6 months with 2 times the recommended daily allowance of iron and zinc, improved vitamin A status as assessed by plasma concentrations of retinol, retinol binding protein (RBP), and transthyretin in children with a high risk of marginal deficiency of zinc, iron, and vitamin A.

There is a little information concerning the roles of micronutrients in different metabolic pathways in the eye, therefore, the aim of this work was study the effect of deficiency or excess of each of vitamin A, zinc or iron either individually or in combination on the cornea, lens and retina of rats.

\section{MATERIALS \& METHODS}

\section{Animals:}

This experiment was done on 48 weanling albino rats, five weeks age with an average weight ranged from 80-100 g, comprised both sexes, obtained from Research Institute of Ophthalmology. The rats were housed in a room controlled for temperature and given access to tap water.

\section{Induction of Zinc Deficiency and} excess:

The three diets were identical except for the amount of zinc carbonate. Zinc-free casein and by the omission of zinc from the mineral mixture, $30 \mathrm{mg} / \mathrm{kg}$ for the zincsufficient diet to serve as control and $60 \mathrm{mg} / \mathrm{kg}$ for the zinc excess diet. Zinc levels in these diets were monitored regularly by atomic absorption spectroscopy. The remaining ingredients were prepared according to the AACC, (1990) ${ }^{(7)}$.

Induction of vitamin A deficiency and excess:

The composition of the vitamin A diets were prepared, vitamin-free casein and by the omission of vitamin A from the vitamin mix. The vitamin A-sufficient diet was prepared by supplementing the basal diet with vitamin A palmitate (1.2 retinol equivalents/g diet) and vitamin $\mathrm{A}$ excess diet was prepared by the adding 2.4 retinol equivalents/g diet as a duple of the amount of that in vitamin A basal diet.

Induction of iron Deficiency and excess:

The composition of the iron diets were prepared, iron-free casein and by the omission of iron from the mineral mixes. The iron-sufficient diet was prepared by supplementing the basal diet with iron carbonate $(180 \mathrm{mg} / \mathrm{kg})$ and the adding $20 \mathrm{~g} / \mathrm{kg}$ added carbonyl iron prepared iron rich diet.

The animals were classified into six groups each group contains eight rats as the following: 
1. Group one served as control was fed on normal basal diet ${ }^{(6)}$.

2. Group two was fed on vitamin A deficient diet.

3. Group three was fed on iron deficient diet.

4. Group four was fed on zinc deficient diet.

5. Group five was fed on diet deficient in all the previous micronutrients (vitamin A, Fe, Zn).

6. Group six was fed on a diet containing excess micronutrients, all previous diets were prepared according to AACC, $(\mathbf{1 9 9 0 )})^{(7)}$.

The animals were fed on the diet for 8 weeks. At the end of the experiment, rats were fasted over night. Blood sample was withdrawn from the eye and the eyeball was isolated then the cornea, lens and retina were separated and stored at $70^{\circ} \mathrm{C}$ till analysis.

Biochemical analysis:

1. Vitamin A was analyzed in serum by using High Performa's liquid Chromatography

2. Iron and zinc were analyzed in pooled sample in each of cornea, lens and retina by the atomic absorption spectrophotometery (Perkin El mer 3300 Germany).

3. Lenses were homogenized in distilled water (336 mg lens $/ \mathrm{ml})$ and centrifuged, the supernatant was separated and total soluble lens protein was estimated according to Lowery $^{(\mathbf{8})}$. Lens proteins were fractionated by using cellogel electrophoresis technique according to the method described by $\boldsymbol{K o h n}^{(9)}$. An automatic scanner (Type Helena 24, Germany) was used for evaluation of the different fractions of the lens soluble protein.

\section{Opthalmological examinations:}

Biomicroscopy and indirect ophthalmoscopy were used in this study to examine the eye.

\section{Histological methods:}

Eyes were enucleated from two rats of each group and were immediately fixed in $4 \%$ glutaraldehyde buffered at $\mathrm{pH}$ 7.3. Retina and cornea, were removed and further fixed in phosphate buffer 1.3\% osmiun tetraoxide ( $\mathrm{pH} 7.3$ ) for 1 hour. The samples were then processed and embedded in araldite CY 212 according to the procedure of Glauret ${ }^{(\mathbf{1 0})}$. Semi - thin sections were cut with an LKB ultratome and stained with toluidine blue and examined with light microscope.

\section{Statistical analysis:}

Experimental data were statistically analyzed by using SPSS. $V$ (10). The results were analyzed using the student-t- test, the probability $\mathrm{P}<0.05$ was considered significant.

\section{RESULTS}

\section{Biochemical results}

The level of vitamin A was lowered in all groups compared with control values, except that group which received excess of all micronutrients (table 1).

The level of zinc in cornea, retina and lens were significantly decreased in the groups fed on vitamin A, and zinc deficiency and in the group with all micronutrient deficient, compared to controls. The higher deficiency was reported in the group fed on the diet that was deficient in all micronutrients. The group with iron deficiency showed a significant 
decreased in the retina only. The group fed on the diet containing excess of all micronutrients showed a significantly increased level of zinc in the cornea; lens and retina (table 2).

The level of iron in cornea, retina and lens is shown in table (3). As shown in this table, the level of iron in different tissues was decreased in the group fed on all micronutrient deficiency. These levels were $074 \pm$ $0.013, \quad \mathrm{P}<0.001, \quad 0.145 \pm 0.006$, $\mathrm{P}<0.01$, and $0.090 \pm 0.008 \mathrm{mg} / \mathrm{g}, \mathrm{p}<$ 0.014 tissue concerning to cornea, retina and lens respectively, while in normal, the values were $0.135 \pm$ $0.008,0.127 \pm 0.002$, and $0.127 \pm$ $0.010 \mathrm{mg} / \mathrm{g}$ tissues respectively. The level of iron in the two groups fed on iron and zinc deficiency was lower than control group in all eye tissues. The most marked decrease was shown in the group fed on deficient of all micronutrients while the values were increased in the group fed on excess of all micronutrients.

The level of total proteins in the lens of different groups was shown in fig (1). As shown in this figure the level of total protein was decreased in all groups except the group, which fed on the diet, contain excess of all micronutrients.
As shown in figs. $(1 \mathrm{~A}-1 \mathrm{~F})$ fractionation of rat lens protein by cellogel paper revealed the existence of eleven fractions belonging to the main 3 types of lens crystallins namely $\alpha, \beta$ and $\gamma$, according to molecular weight range and electrophoretic mobility, ${ }^{12}$ fractions 1 4 were identified as representing $\gamma$ crystallin, fractions 5-10 representing $\beta$-crystallin and fraction 11 representing $\alpha$-crystallin.

As shown in Fig (1) and table (4), the protein content of control lens was $195 \mathrm{mg} / \mathrm{g}$-wet wt. The sum of fractions representing $\gamma$-crystallin was $97.5 \mathrm{mg} / \mathrm{g}$ wet wt $(50 \%)$, and that of $\beta$ crystallin was $68.25 \mathrm{mg} / \mathrm{g}$ wet wt $(35.1 \%)$ and the $\alpha$-fraction was 29.05 $\mathrm{mg} / \mathrm{g}$ wet wt $(14.9 \%)$. As shown in the same table, there was a decrease in $\alpha, \beta$ and $\gamma$ fractions in animals fed on a diet-deficient in vitamin A, iron, and zinc and in all micronutrients than the control group.

The most marked deficiency in the soluble lens protein was found in the group fed on a diet deficient in zinc, which was $21.3 \mathrm{mg} / \mathrm{g}$-wet wt.

The group of animals fed on excessive vitamin $\mathrm{A}$, iron and zinc showed a higher value of lens soluble protein that which was $185 \mathrm{mg} / \mathrm{g}$-wet wt.

Table (1): The level of serum vitamin A of control and different groups studied

\begin{tabular}{|l|l|l|}
\hline \multicolumn{1}{|c|}{ Groups } & \multicolumn{1}{c|}{ Vitamin A ( $\mathbf{\mu g} / \mathbf{d l})$} \\
\cline { 2 - 3 } & \multicolumn{1}{|c|}{ Mean \pm S.E. } & \multicolumn{1}{c|}{$\mathbf{P}$} \\
\hline Control & $25.88 \pm 0.037$ & $0.001^{*}$ \\
\hline Vitamin A free & $15.2 \pm 0.79$ & $0.001^{*}$ \\
\hline Iron free & $10.58 \pm 0.23$ & $0.001^{*}$ \\
\hline Zinc free & $10.36 \pm 0.34$ & $0.001^{*}$ \\
\hline Vitamin A, iron, zinc free & $8.34 \pm 0.20$ & $0.001^{*}$ \\
\hline Excess vitamin A, iron, zinc & $31.23 \pm 0.40$ & $0.001^{*}$ \\
\hline P $<0.05=$ significant difference between control compared to different groups of the \\
study
\end{tabular}


Table (2): The level of zinc in cornea, lens and retina of control and different groups studied.

\begin{tabular}{|l|c|c|c|c|c|c|}
\hline \multicolumn{1}{|c|}{ Tissues } & \multicolumn{2}{c|}{$\begin{array}{c}\text { Cornea } \\
\text { mg/g tissue }\end{array}$} & \multicolumn{2}{c|}{$\begin{array}{c}\text { Retina } \\
\text { mg/g tissue }\end{array}$} & \multicolumn{2}{c|}{$\begin{array}{c}\text { Lens } \\
\text { mg/g tissue }\end{array}$} \\
\hline & Mean \pm S.E. & $\mathrm{P}<$ & Mean \pm S.E. & $\mathrm{P}<$ & Mean \pm S.E. & $\mathrm{P}<$ \\
\hline Control & $0.238 \pm 0.021$ & - & $0.395 \pm 0.013$ & - & $0.169 \pm 0.013$ & - \\
\hline $\begin{array}{l}\text { Vitamin A } \\
\text { free }\end{array}$ & $0.065 \pm 0.005$ & 0.006 & $0.0235 \pm 0.012$ & 0.007 & $0.120 \pm 0.016$ & 0.032 \\
\hline Iron free & $0.236 \pm 0.016$ & 0.963 & $0.209 \pm 0.027$ & 0.003 & $0.151 \pm 0.002$ & 0.207 \\
\hline Zinc free & $0.045 \pm 0.011$ & 0.006 & $0.189 \pm 0.016$ & 0.007 & $0.078 \pm 0.023$ & 0.004 \\
\hline $\begin{array}{l}\text { Vitamin A, } \\
\text { iron, zinc free }\end{array}$ & $0.076 \pm 0.026$ & 0.0002 & $0.241 \pm 0.005$ & 0.008 & $0.065 \pm 0.009$ & 0.005 \\
\hline $\begin{array}{l}\text { Excess } \\
\text { vitamin A, } \\
\text { iron, zinc }\end{array}$ & $0.336 \pm 0.012$ & 0.001 & $0.493 \pm 0.009$ & 0.005 & $0.25 \pm 0.026$ & 0.011 \\
\hline
\end{tabular}

Table (3): The level of iron in different ocular tissues studied.

\begin{tabular}{|l|c|c|c|c|c|c|}
\hline \multirow{2}{*}{ Groups } & \multicolumn{2}{c|}{$\begin{array}{c}\text { Cornea } \\
\text { mg/g tissues }\end{array}$} & \multicolumn{2}{c|}{$\begin{array}{c}\text { Retina } \\
\text { mg/g tissue }\end{array}$} & \multicolumn{2}{c|}{$\begin{array}{c}\text { Lens } \\
\text { mg/g tissue }\end{array}$} \\
\cline { 2 - 7 } & Mean \pm S.E & $\mathrm{P}<$ & Mean \pm S.E & $\mathrm{P}<$ & Mean \pm S.E & $\mathrm{P}<$ \\
\hline Control & $0.135 \pm 0.008$ & - & $0.127 \pm 0.002$ & - & $0.127 \pm 0.010$ & \\
\hline $\begin{array}{l}\text { Vitamin A } \\
\text { free }\end{array}$ & $0.139 \pm 0.006$ & 0.722 & $0.131 \pm 0.012$ & 0.755 & $0.112 \pm 0.005$ & 0.219 \\
\hline Iron free & $0.069 \pm 0.008$ & 0.005 & $0.080 \pm 0.010$ & 0.0003 & $0.053 \pm 0.005$ & 0.005 \\
\hline Zinc free & $0.140 \pm 0.023$ & 0.844 & $0.116 \pm 0.019$ & 0.585 & $0.094 \pm 0.019$ & 0.156 \\
\hline $\begin{array}{l}\text { Vitamin A, } \\
\text { iron, zinc } \\
\text { free }\end{array}$ & $0.074 \pm 0.013$ & 0.001 & $0.145 \pm 0.006$ & 0.01 & $0.090 \pm 0.008$ & 0.014 \\
\hline $\begin{array}{l}\text { Excess } \\
\text { vitamin A, } \\
\text { iron, zinc }\end{array}$ & $0.187 \pm 0.015$ & 0.008 & $0.366 \pm 0.029$ & 0.006 & $0.201 \pm 0.027$ & 0.023 \\
\hline
\end{tabular}


Fig. (1): Electrophoretic separation of lens crystallin of control and different groups.
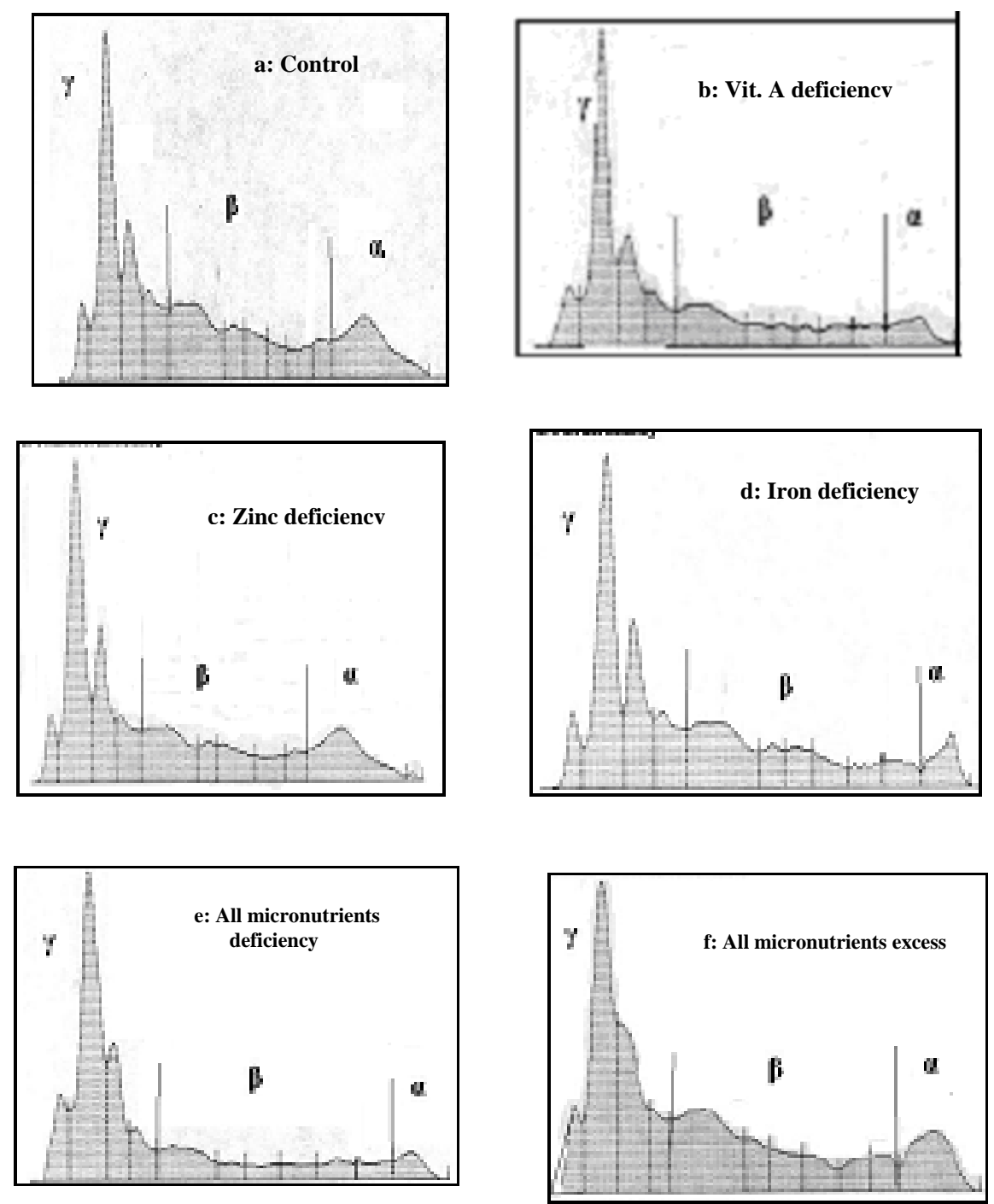
Table (4): The Concentrations and the percentage distribution of rat lens crystallin in different groups

\begin{tabular}{|l|c|c|c|c|c|c|c|}
\hline \multirow{2}{*}{ Garameter } & $\begin{array}{c}\text { Total lens } \\
\text { protein }\end{array}$ & \multicolumn{2}{|c|}{$\gamma$ - Fraction } & \multicolumn{2}{c|}{$\beta$-fraction } & \multicolumn{2}{c|}{$\alpha$ - fraction } \\
\cline { 2 - 9 } & $\begin{array}{c}\mathrm{mg} / \mathrm{g} \\
\text { wet } \mathrm{wt}\end{array}$ & $\begin{array}{c}\mathrm{mg} / \mathrm{g} \\
\mathrm{wet} \mathrm{wt}\end{array}$ & $\%$ & $\begin{array}{c}\mathrm{mg} / \mathrm{g} \\
\text { wet } \mathrm{wt}\end{array}$ & $\%$ & $\begin{array}{c}\mathrm{mg} / \mathrm{g} \\
\text { wet wt }\end{array}$ & $\%$ \\
\hline Control & 195 & 97.5 & 50.0 & 68.25 & 35.1 & 29.05 & 14.9 \\
\hline Vitamin A free & 144 & 77.04 & 53.5 & 66.38 & 46.1 & 0.57 & 0.4 \\
\hline Iron free & 93.0 & 53.2 & 57.2 & 34.31 & 36.9 & 5.49 & 5.9 \\
\hline Zinc free & 21.3 & 14.57 & 68.4 & 5.69 & 26.7 & 1.04 & 4.9 \\
\hline Vitamin A, iron, zinc free & 85.03 & 53.82 & 63.1 & 25.68 & 30.1 & 5.8 & 6.8 \\
\hline Excess vitamin A, iron, zinc & 185.0 & 94.5 & 33.4 & 71.00 & 24.91 & 19.50 & 6.69 \\
\hline
\end{tabular}

Ophthalmological examination:

The results of ophthalmological examination showed that secterical cataract (cortical cataract) was found in the groups fed on deficient or excess of all micronutrients.

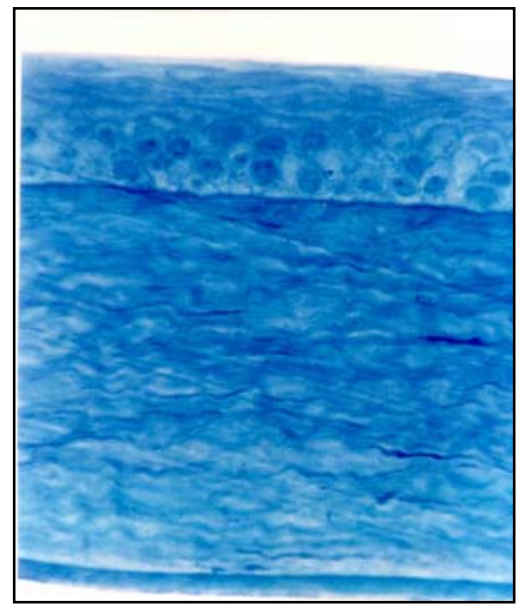

(Fig. 2A): Light micrograph of rat cornea fed on control diet showing its normal layers stratified squamous non - keratinized epithelium (EP), Bowmen's layer (B), substantia propria (S), Descemet's membrane (DE) and endothelium (E). (Toluidine blue, $x$ 500).
Histological results

Group 1: (control diet)

No significant microscopic alterations were seen in the retina and cornea of rats on normal diet, Toluidine blue X 500. (Fig. 2A, 2B).



(Fig. 2B): Light micrograph of rat retina fed on control diet showing normal appearance of all retinal layers. Toluidine blue, $x 500$. 


\section{Group 2: (vitamin A deficiency}

\section{(A) cornea}

Fig. 3A): Light micrograph of rat cornea fed on vitamin A deficient diet showing significantly irregular arrangement of epithelial cells and irregular arrangement of stromal collagen. Also a deeply stained keratocytes and endothelium with vacuolated cytoplasm. Toluidine blue, $\mathrm{x}$ 1250 .

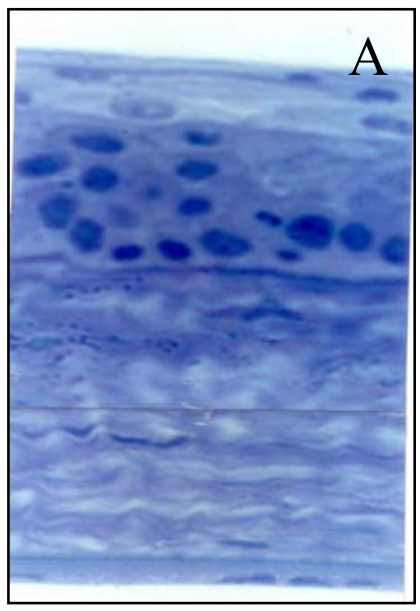

\section{(B) The Retina}
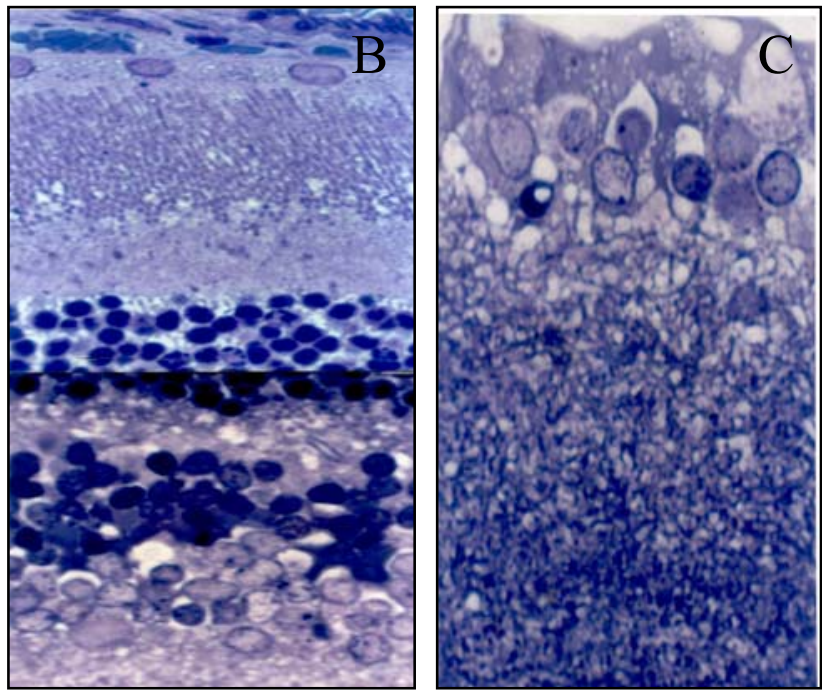

(Fig. 3B \& C): Light micrograph of rat retina fed on vitamin A deficient diet showing the inner plexiform layer (IPL) appear oedematous. The ganglion cell nuclei appear swollen with margentation of their chromatin and the cytoplasm contains many vacules (V) .The nerve fiber layer (NFL) appear vaculated. Toluidine blue, $\mathrm{x} 1250$. 


\section{Group 3 (iron deficiency)}

\section{(A) Cornea}

(Fig. 4A): Light micrograph of rat cornea feed on iron deficient diet showing lacking of columnar basal cells appearance, keratinization and irregular stromal appearance, densified keratocytes and vaculation of endothelium. Toluidine blue, x 1250.

\section{(B) Retina}



(Fig. 4B): Light micrograph of retina of rats fed on iron deficient diet showing swollen of nuclei of retinal pigment epithelium (RPE), disorganization of photoreceptor layer and densification of nuclei of outer nuclear layer. Toluidine blue, $\mathrm{x}$ 1250.
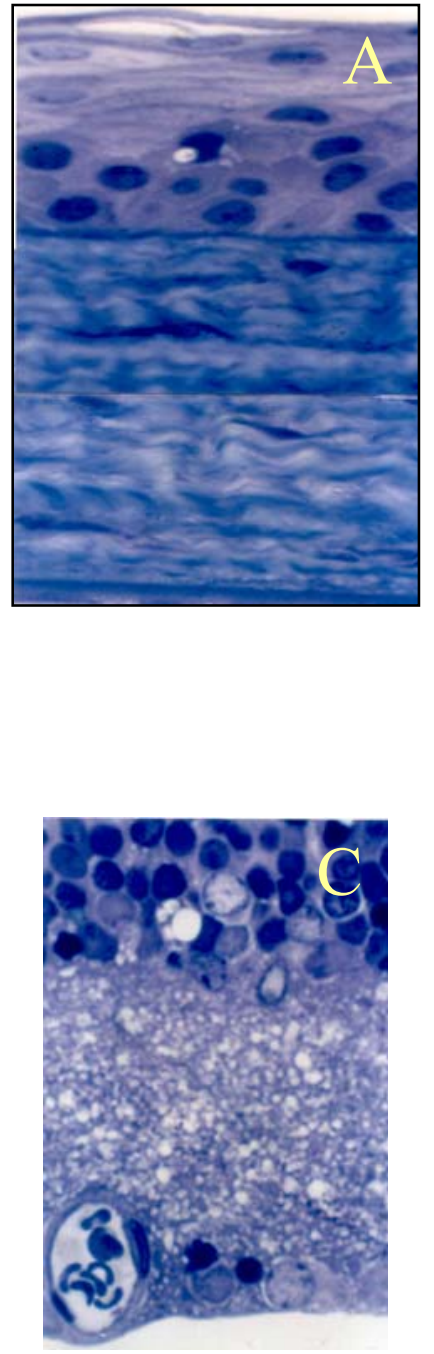

(Fig. 4C): Light micrograph of retina of rats fed on iron deficient diet showing swollen of the inner nuclear cells, oedematous appearance of inner pflexiform layer and margination of nuclear chromatin of ganglion cell nuclei. Toluidine blue, $\mathrm{x} 1250$. 


\section{Group 4 (zinc deficiency)}

(A) Cornea

(Fig 5A): Light micrograph of rat cornea fed on zinc deficient diet showing lacking of columnar appearance of basal cells, irregular stromal collagen and presence of blood vessel (V) and endothelium with ruptured posterior border. Toluidine blue, $\mathrm{x} 1250$.

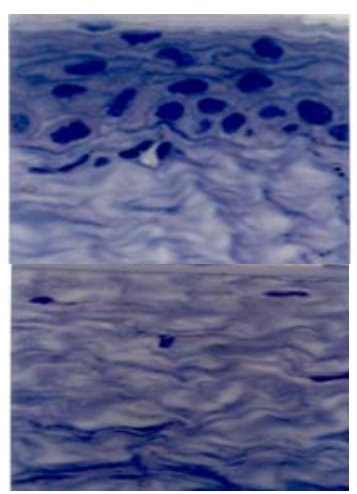

\section{(B) Retina}
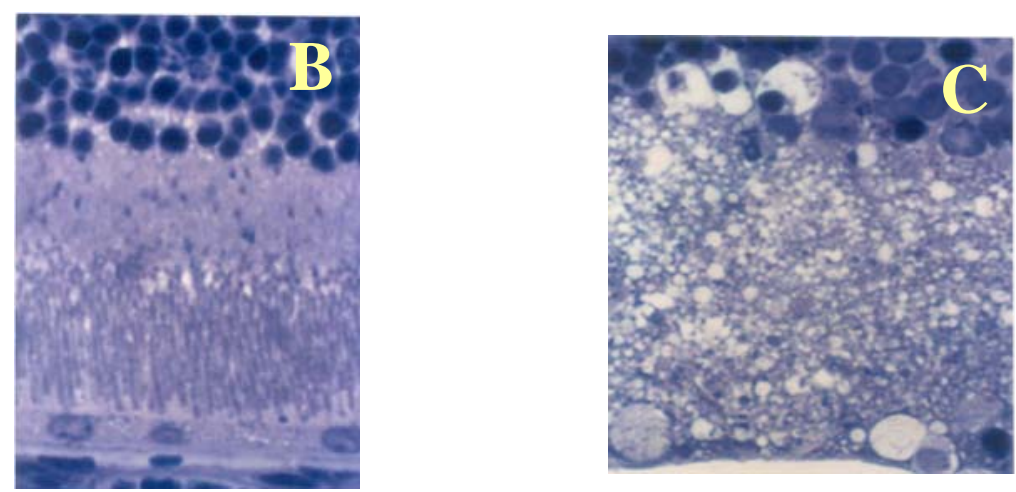

(Fig 5B): Light micrograph of rats retina fed on zinc deficient diet showing swollen nuclei of pigment epithelium with vaculated cytoplasm, fragmented of photoreceptor outer segments (OS) and pyknosis of nuclei of outer nuclear layer (ONL). Toluidine blue, x 1250.

(Fig 5C): Light micrograph of rat retina fed on zinc deficient diet showing densified nuclei of inner nuclear layer (INL) and swollen nuclei of ganglion cells with faintly chromatin. Toluidine blue, x 1250. 


\section{Groups 5 - (deficient in all micronutrients)}

(A) Cornea:

(Fig. 6A): Light micrograph of rat cornea fed on deficient diet showing thinning of epithelium layer and oedema of stroma. Toluidine blue x 1250

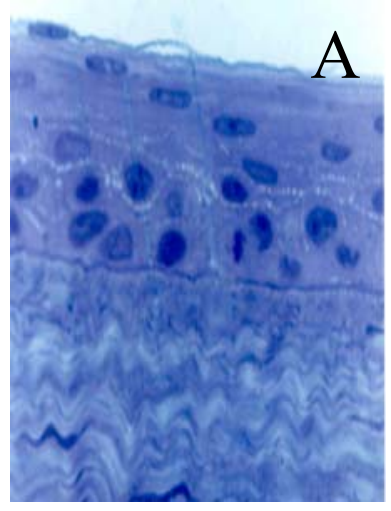

\section{(B) Retina:}

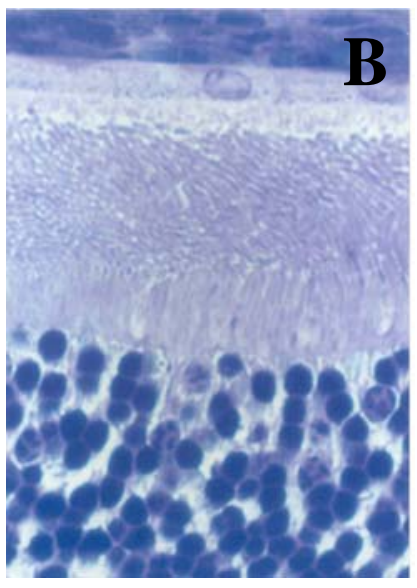

(Fig. 6B): Light micrograph of rat retina fed on deficient in all micronutrients showing swollen nuclei of pigment epithelium (EP) fragmented photoreceptor outer segments (OS) and densified outer nuclear layer nuclei. Toluidine blue x 1250 .

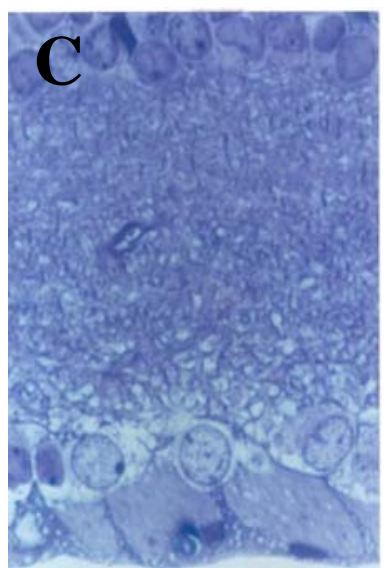

(Fig. 6C): Light micrograph of rat retina showed swollen nuclei of inner nuclear layer and ganglion cell layer. Toluidine blue x 1250 
Group (6): (excess of all micronutrients) (A) Cornea:

(Fig.-7A): Light micrograph of rat cornea revead loss of epithelium architecture, and irregularity of stromal lamellae. Toluidine blue, x 1250 .

(B) Retina: (excess of all micronutrients)

(Fig. 7B): Light micrograph showing slight fragmentation of photoreceptor outer segments (0S) and pyknosis of nuclei of outer nuclear layer. Toluidine blue, x 1250 .

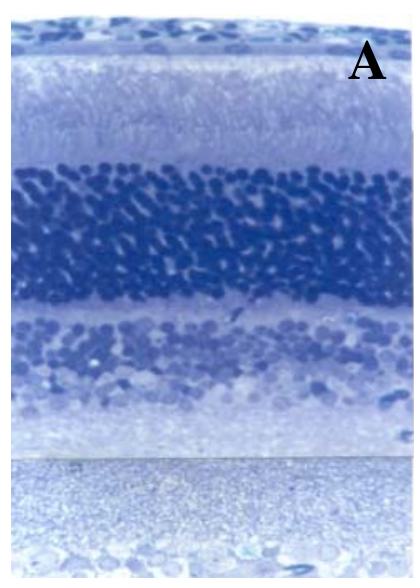




\section{DISCUSSION}

Nutritional associations have been found with major eye diseases, which is a leading cause of severe visual impairment or blindness ${ }^{(\mathbf{1 2})}$. The importance of attaining adequate macronutrient and micronutrient intake throughout the life course is essential for maintenance of health ${ }^{(13)}$. Micronutrients deficiency is regarded as one of the widespread risk factors contributing to different eye diseases $^{(\mathbf{1 4 )}}$. Zinc influences cell metabolism through a variety of mechanisms. It appears to play an integral role in maintaining normal ocular functions.

The results of the current study showed that the level of vitamin A in serum (Fig.1) and the level of zinc in cornea, lens and retina (Table 1) were low in all groups. However in the group of excess in all micronutrients, vitamin A level was increased. The interaction between zinc deficiency and vitamin A metabolism have been reported by Brown and Munoz ${ }^{(15)}$ who found that zinc deficiency is commonly associated with low plasma concentrations of vitamin A even when hepatic vitamin A stores are normal, suggesting that there is a defect in mobilization of vitamin A rather than in its absorption or transport to the liver. The interaction between zinc and vitamin A in the eye was studied by Shingwekar and ELMarsafey $^{(16,17)}$, who found that zinc supplementation would improve the level of vitamin A deficiency in the children with protein malnutrition. Newsome,et al. ${ }^{(18)}$, suggested that, the dark adaptation did not return to normal in patients treated only with vitamin A until, zinc was added to the treatment regimen. Several studies $^{(\mathbf{1 9}, 20)}$, showed the interaction between vitamin $\mathrm{A}$ and iron. They demonstrated that vitamin A deficiency causes abnormalities in iron metabolism and supplementation with vitamin A improves iron status. Strong correlation between zinc, vitamin A and iron were also demonstrated by Kolsteren ${ }^{(4)}$.

The author suggested that, the addition of vitamin $\mathrm{A}$ and zinc to the treatment of anemia can increase hemoglobin levels more than with iron alone.

Biochemical assay of zinc, vitamin $\mathrm{A}$ and iron was confirmed by histological results in cornea and retina. The present study suggested that the change in these tissues may be due to the importance role of zinc, vitamin $\mathrm{A}$ and iron as antioxidant to maintain healthy ocular tissue against peroxide damage which induced as a result of deficiency in these micronutrients. The presence of peroxidative damage in ocular tissues has been demonstrated in the retina and cornea $^{(21)}$. The results of the present study confirms these findings and suggested that, the low level of micronutrients causes ocular tissue damaging may be due to decrease in zinc and iron which are considered to be important for improve the level of antioxidant enzymes such as superoxide dismutase and catalase. These enzymes depend on zinc and iron in their metabolism. The alteration of the redox potential is thought to be closely associated with the changes in corneal and retinal cells of rats deficient in these micronutrients. 
Treatment with vitamin A and zinc showed protective effect from cataract $^{(22)}$ controversially, Wczynski, et al. $^{(23)}$ found an increased content of zinc and iron in human cataractous lens ${ }^{(24)}$. The current study showed increased levels of zinc, iron and also vitamin $\mathrm{A}$ in cornea, lens and retina in the group fed on a diet with excess in all micronutrients.

On the other hand the results of this study showed a deficiency in the level of total protein in all groups especially the group of rats fed on zinc deficient diet, where the level of total protein was markedly decreased to $21.3 \mathrm{mg} / \mathrm{g}$-wet wt in the lens and $20.7 \mathrm{mg} / \mathrm{g}$-wet wt in retina. Munoz ${ }^{(5)}$ reported that the decrease in the total protein level in the presence of zinc deficiency might be due to impairment in protein synthesis. This impairment affects retinol (vitamin A) transport from the liver to the circulation. In addition, zinc deficiency decreased the level of serum albumin, prealbumin, transferrin and retinol binding protein. Richard and Blemings ${ }^{(25)}$ and Kolsteren $^{(4)}$ stated that impairment in proteins and retinol binding protein interferes with synthesis of glycoprotein, transferrin, and total iron- binding capacity which in turn leads to impairment in iron transport and protein synthesis. In the current study the analysis of soluble lens proteins and its fractionation on cellogel (Fig. 1) and (table 4) showed quantitative changes in lens crystallins of rats fed on diet deficient in zinc, iron, vitamin A and also in rats fed on a diet deficient in all the micronutrients. The pattern obtained showed a decrease in the concentration of $\gamma-, \quad \beta$-and $\alpha-$ crystallins in all the previous groups mentioned above. This is may be due to decrease in total proteins.

The change in the pattern in the groups fed on either excess or deficient of all micronutrients may be due to the aggregation of low molecular weight crystallins and render them insoluble which leads to lens opacity and cataract ${ }^{(26)}$.

The results of ophthalmological examination showed that secterical cataract (cortical cataract) was found in the groups fed a diet contain deficient or excess of all micronutrients. These data suggested that, there is a possible influence of zinc and iron content on the development of cataract via precipitation of these minerals in the lens causing aggregation of lens crystallin and hence induced cataract.

On the other hand, toxicities related to excess of zinc, iron and vitamin A have been reported previously in human and animal eyes ${ }^{(26,27)}$. The current study suggested that the excess of the micronutrients (zinc, iron and vitamin A) might play a role in the mechanism of the developmental cataract.

Histological study showed a change in the cornea of rat fed on vitamin A deficient diet in the form of irregular arrangement of epithelial cells, deeply stained keratocytes and vacuolated endothelium. This was in agreement with Van Horn ${ }^{(28)}$, who stated that keratinized epithelial cells were present on the surface of the cornea.

The retina of the same group showed changes in the pigment epithelium layer and photoreceptor 
layer. Edema was found in the inner plexiform layer and the nerve fiber layer appeared vacuolated which is in agreement with Gordon and John ${ }^{(29)}$ who found that there is photoreceptor degeneration, due to vitamin A deprivation.

The cornea of rats fed on iron deficient diet showed lacking of columnar basal cell and keratinization with evaculation of endothelium, while the retina of the same group showing disorganization of photoreceptor, and edema in the inner plexiform layer.

The results of the present study reported that deficiency of iron caused damage to the photoreceptor cells of the rat retina as finding by Williams and Lett $^{(30)}$.

In case of rats fed on zinc deficient diet, the histological studies of the cornea showed irregular stromal collagen and presence of blood vessels with ruptured posterior broders of endothelium. Leure ${ }^{(31)}$ found neovascularization of the anterior stroma of the rat cornea with prolonged zinc deficiency. The retina of rat fed on zinc deficient diet showed a fragmentation of photoreceptor outer segment and pyknosis of nuclei of outer nuclear layer. This result was in agreement with Newsome, et $\boldsymbol{a l}^{\left(\mathbf{r}^{(32)}\right.}$ who stated that histological abnormalities in the retina was seen in animals fed on a diet deficient in zinc.

The cornea of rats fed on a diet deficient in all micronutrients; the histological studies showed a severe thinning of epithelium layer and edema of the stroma. While, the retina of the same group showed fragmentation of photoreceptor, outer segments and densify of outer nuclear layer. Biochemical studies confirmed this result, which showed severe deficiency in iron and zinc in both cornea and retina, due to the interaction between vitamin $\mathrm{A}$, zinc and iron deficiency $(5,19,20)$.

The histological studies of the cornea of rats fed on a diet containing excess of all micronutrients showed a loss of epithelium architecture and irregularity of stromal lamellae. Also, the retina of the same group showed fragmentation of photoreceptor outer segments and pyknosis of nuclei of outer nuclear layer. This finding was confirmed by Kato and Niitsu, Barlett and Eperjesi ${ }^{(25,26)}$.

In conclusion, all persons should be encouraged to maintain healthy nutrition. Middle aged and elderly patients may be benefit from supplement. The intake of excess of the recommended daily allowances may be toxic. This work recommended that zinc, iron and vitamin A should be included in nutrition supplement according to Recommended Daily Allowances to maintain ocular function and for prevention of the onset or progression of different eye diseases.

\section{REFERENCES}

1. Gibson, R.S. (2003): Strategies for preventing micronutrient deficiencies in developing countries. Asia Pac J Clin Nutr.; 13 (Suppl):S23.

2. Martin, L.K.; Kenton, R.P.; Garry, J.H.; Terri, L. B. and Edward A. D. (1982): Effect of antioxidant nutrient deficiency on the retina and retinal pigment 
epithelium of albino rats: a light and electron microscopic study. Exp. Eye Res.; 34, 339 - 369.

3. Grahn, B.H.; Paterson, P.G.; Gottschall-Pass, K.T.; and zhang, Z.(2001): Zinc and the eye. J Am. Coll. Nutr. 20 (2 suppl) : $106-118$.

4. kolsteren, P.; Rahman, S.R; Hilerbrnd, k.; and Diniz, A. (1999): Treatment for iron deficiency anemia with a combined supplementation of iron, vitamin A and zinc in women of Bangladesh. European J. of Clinic. Nutr. 53, 102-106.

5. Munoz, E .C.; Rosado, J. L.; and Lindsay $H$.A. (2000): Iron and zinc supplementation improves indicators of vitamin A status of Mexican preschoolers. Am . J. Clinic .Nutr. 71:789 -94.

6. Lane Peter and Pearson (1971): Dietary requirement in the laboratory animal. Principals and practice.P142 Academic Press. London, New York.

7. Proved method of American association of cereal chemist published by Am. Ass. of Cereal Chemistry, (1990) INS. ST. POUN, MINNESOTA, USA.

8. Lowery, O.H.; Rosebrough, N.J.; Farr, A.L.; and Randall, R.J. (1951): Protein measurement with the folin phenol reagent. $J$ Biol. Chem., 193, 265-275.

9. Kohn, J. (1968): Cellulose acetate electrophoresis and immunodiffusion techniques. In chromatographic and Electrophoretic techniques (Ed.by smith 1) Inter Scinse Pub., New York, vol11,PP48.
10. Glauret, A.M. (1965): The fixation and embedding of biological specimen. In: Techniques for electron microscope. D. H. Key, ed. Davis Co., Philadelphia, pp. 166-212.

11. Peyman, A. G.; Donland, R. S.; and Morten, F.G. (1980): Principles and practice of ophthalmology. pp.489, W.B. Saunders Co., Philadelphia, London, Toronto.

12. Mitchell, P; Smith, W; Cunming, R.G; and Rochtchina, E. (2003): Nutritional factors in the development of age related eye disease. Asia Poc J clin Nutr .12 Suppl : 55.

13. Dangour, A.D.; Sibson, V.L.; and Fletcher, A.E. (2004): Micronutrient supplementation in later life: limited evidence for benefit . J geronlal A Boil. Sci. Med. Sci,59:659-73.

14. Wegener, A.; Heinitz, M.; and Dwinger, M. (2002): Experimental evidence for interactive effects of chronic $\mathrm{U} \mathrm{V}$ irradiation and nutritional deficiencies in the lens. Dev. Ophthalmol. 35:113-124.

15. Brown, N.A.; Bron, A.J.; and Harding, J.J. (1998): Nutrition supplements and the eye .Eye. 12: 127 - 33.

16. Shingwekar, A. G.; Mohanram, M., and Reddy, V. (1979): Effect of zinc supplementation on plasma levels of vitamin A and retinol binding protein in malnourished children. Clin. Chim. Acta., 93:97 - 100 .

17. El - Marsafy, A.; Anhar, M.G.; Sawsan, H.K.; and Fardous, S. 
(1998): Role of Zinc and vitamin A supplementation in the nutritional rehabilitation on of protein energy malnutrition. Bul. of Physiological Since. 18: 1-18.

18. Newsome, D.A.; Swartz, M.; Leono, N.C.; and Miller, E. (1988): Oral zinc in macular degeneration. Arch. Ophth. 108; 192- 198.

19. Bloem, M.W. (1995): Interdependence of vitamin A and iron an important association for programmes of anemia. Control. Proc . Nutr. Soc.54:501-508.

20. Bloem, M.W.; Weded, M.J.; Gtmaal, E.J.; and Schreurs, W.H.P. (1990): Vitamin A intervention: short term effects of a single, oral, massive dose on iron metabolism. Am. J .Clinic. Nutr.51:76-79.

21. Hayashi, S.; Ishimoto, S.; Wu, G. S.; Wee, W. W.; and Donnell, P.C. (1997): Oxygen free radical damage in the cornea after excimer laser therapy . Br. $J$. Ophthalmol. 81:141 - 144 .

22. Bunce, G. E. (1994): Evaluation of the impact of nutrition intervention on cataract prevalence in China. Nutrition Reviews, 52, 3, $99-101$.

23. Wczynski, J.; Blum. M.; and Strobel, J. (2002): Increased content of zinc and iron in human cataractous lens. Biol Trace Element Res . 90: I - 6.

24. Kato, J. and Niitsu, Y. (2002): Recent advance in molecular iron metabolism Translational disorders of ferritin. Int.J. Hematol, 76:208-212.
25. Richard, S. and Blemings, K.P. (1998): Iron regulatory proteins, iron responsive elements and iron homeostasis. Am. J. Clinic. Nutr.59:176-179.

26. Barlett, $H$. and Eperjesi, $F$. (2004): An ideal ocular nutritional supplementation? Ophthalmic physiol. Opt. 24: 339-349.

27. Liang, J.N.; and Li, X. (1991): Interaction and aggregation of lens crystallins EXP. Eye Res. 53:61.

28. Van Horn, D.L.; Schutten, W.H.; Hyndiuk, R.A.; and Kur, p. (1980): Xerophthalmia in vitamin A deficient rabbits. Clinical and ultra-structural alterations in the cornea. Invest. Ophthol. Vis. Sci. 19 (9): 10671097.

29. Gordnon, L.F.; and John, E. L. (1993): Photoreceptor degeneration in Vitamin A deprivation and retinitis pigmentosa: the equivalent light hypothesis . Exp. Eye Res. 57, 335- 340.

30. Williams, G. R.; and Lett, J. T. (1996): Damage to the photoreceptor cells of the rabbit retina from $56 \mathrm{Fe}$ ions: effect of age at exposure, Adv Space. Res. $18(1-2): 55-58$.

31. Leure-Dupree, A.E. (1986): Vascularization of the rat cornea after prolonged zinc deficiency. Anal Res. 216 (1): 27 - 32.

32. Newsome, D.A.; Mano, S.; Leone, N.C.; Elston, R.C.; and Earl, M. (1988): Oral zinc in macular degeneration. Arch. Ophthalmo.; 106, 192-198. 
دراسة بيوكيميائية وهستولوجية عن التقاعل بين الغذيات الدقيقة مثل فيتامين

\section{(أ) والحديا والزتك فى العين}

"مرجريت عزدى عزبز،* أنهار محد جدعة شهاب،" ليلى كمال حنفى،

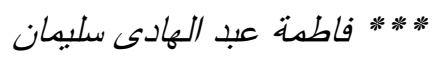

*قسم الكيمياء الحيوية و التغذية، **قشم الهستولوجى،

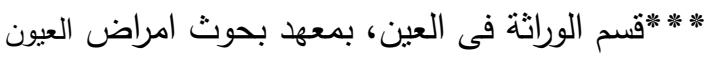

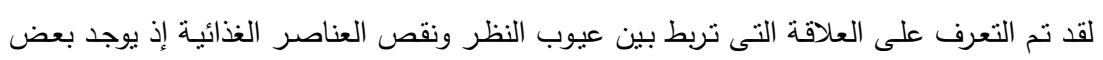

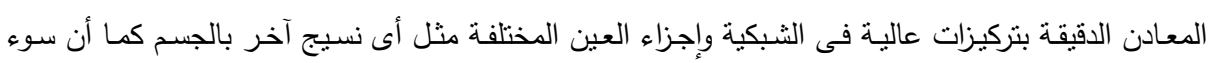

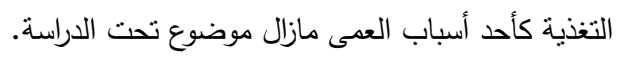



والحديد والزنك وتأثير ذلك على العين.

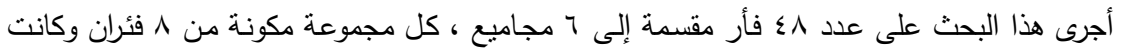

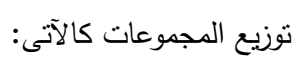

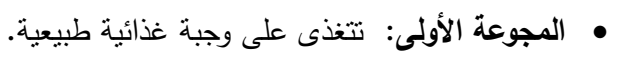

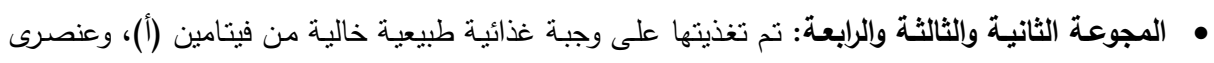

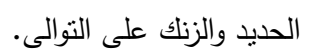

• المجوعة الخامسة: تم تغذيتها على الوجبة الغذائية الطبيعية الخالية من العناصر السابقة معاً.



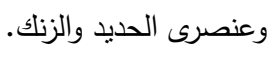

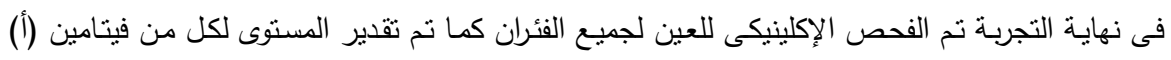



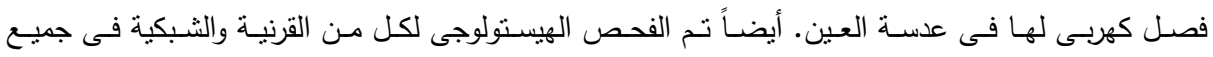

$$
\text { المجموعات تحت الدراسة. }
$$

أوضحت هذه الدراسة وجود مياه بيضاء فى عدسة العين بالمجموعتين المتغذيتين على نقص وزيادة

العناصر الغذائية الدقيقة المختلفة ، كما وجدت نقص ملحوظ فى مستوى كل من فيتامين (أ) والحديد والزنائك

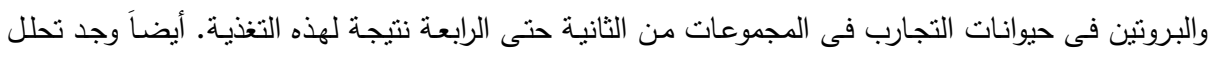

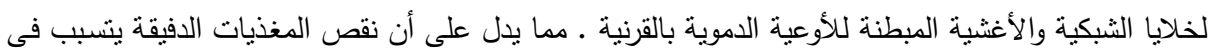



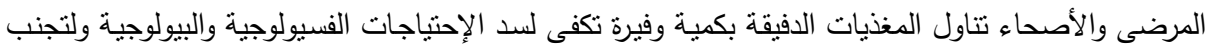

$$
\text { المضاعفات التى تحدث بالعين. }
$$

